\title{
Serum Adropin Levels in a Preeclampsia Like L-Name Rat Model Treated with Sildenafil Citrate
}

\author{
NADINE A. RAAFAT, M.D. and MAHA A. FATHY, M.D. \\ The Department of Physiology, Faculty of Medicine, Zagazig University, Egypt
}

\begin{abstract}
Background: Preeclampsia, a hypertensive disorder of pregnancy, is detrimental to both mother and fetus. Sildenafil been proposed as a potential therapy to reduce blood pressure and improve uteroplacental perfusion in preeclamptic patients. Adropin is a novel secreted energy homeostasis protein regulating carbohydrate, lipid and protein metabolism, maternal adropin levels in Preeclampsia were still controversy.
\end{abstract}

Aim of the Work: To evaluate serum levels of adropin in preeclampsia-like rat model and in preeclamptic rats treated with Sildenafil and to investigate their associations with some inflammatory, oxidative stress, and metabolic parameters.

Material and Methods: 32 pregnant rats were divided randomly into four groups $(\mathrm{n}=8)$ : Control group, sildenafil treated group, L-NAME group to induce pre-eclampsia and L-NAME with sildenafil treated group. In all groups, maternal Body Mass Index (BMI), placental weights, fetal weights, maternal mean arterial blood pressure (MAP), total urinary proteins, serum glucose, insulin and calculated Homeostatic Model Assessment of Insulin Resistance index (HOMA-IR), serum urea, creatinine, Triglycerides (TGs), Total Cholesterol (TC), Low Density Lipoproteins-cholesterol (LDL-c), High Density Lipoproteins-cholesterol (HDL-c), C Reactive Protein (CRP), Endothelin-1 (ET-1), and adropin were measured, also placental Malondialdehyde (MDA) levels, and activities of the antioxidant enzymes Superoxide Dismutase (SOD) and glutathione peroxidase (GSH) in placental homogenates were determined plus histopathological examination of placental sections were done.

Results: L-NAME induced preeclampsia in rats and they showed significant increase in MAP, total urinary proteins, serum levels of glucose, insulin, calculated HOMA-IR, serum urea, creatinine, CRP, ET-1, TGs, TC, LDL-c, adropin and placental tissue MDA with significant reduction in maternal BMI, placental weights, fetal weights, serum HDL-c and placental tissue SOD and GSH activities as compared to other groups, additionally, L-NAME treated and L-NAME + SILD treated groups revealed positive significant correlations between adropin levels and MAP, total urinary proteins, serum levels of urea, creatinine, CRP, ET-1, TGs, TC, LDL-c, and placental tissue MDA, however they showed negative correlations between adropin and BMI, placental weights, fetal

Correspondence to: Dr. Nadine A. Raafat, E-Mail: nadraf77@yahoo.com weights, serum HDL-c and placental tissue SOD and GSH activities.

Conclusion: Increased maternal adropin levels in preeclampsia like model in rats might represent a regulatory feedback mechanism against endothelial placental dysfunction, insulin resistance, inflammation and oxidative stress which associated with preeclampsia, hence identify it as a potentially protective agent against preeclampsia development. Sildenafil ameliorates preeclampsia symptoms, inflammation and oxidative stress in a rat model of preeclampsia.

Key Words: Adropin - Sildenafil citrate - LNAME - Preeclampsia-Rats.

\section{Introduction}

PREECLAMPSIA (PE) is defined by the development of hypertension and proteinuria after 20 weeks of gestation in previously normotensive non-proteinuric pregnant women $[1,2]$. It has been suggested that PE is a two-stage disorder starting by placental under-perfusion or ischemia (Stage I) followed by secretion of many soluble factors into the maternal circulation with subsequent endothelial dysfunction and multiple organ injuries responsible for its clinical manifestations (Stage II) $[3]$

As Nitric Oxide (NO) deficiency has been suggested as a contributory factor in pre-eclampsia [4], chronic inhibition of Nitric Oxide Synthase (NOS) in pregnant rats by $\mathrm{N}$ (omega)-nitro-Larginine methyl ester (L-NAME), during mid- to late gestation, results in pre-eclampsia like symptoms such as hypertention, severe renal vasoconstriction, proteinuria, thrombocytopenia and IntraUterine Growth Retardation (IUGR) [5]

Sildenafil citrate is a type 5-specific phosphodiesteras inhibitor that inhibits the degradation of nitric oxide leading to vasodilation [6] and increasing fetoplacental blood flow in case of placental vascular insufficiency and preeclampsia [7]. 
Adropin is a peptide hormone that is encoded by the energy homeostasis-associated (ENHO) gene. It has been shown to be released in many tissues such as central nervous system, liver, the heart and skeletal muscles [8]. Moreover, it is secreted by vascular endothelium and up regulates Vascular Endothelial Growth Factor 2 (VEGF2) and endothelial Nitric Oxide Synthase (eNOS) which take part in neovascularization [9]. Circulating adropin concentrations are highly regulated by energy intake as well as being involved in cardiovascular function, particularly in endothelial function [10]. In animals, adropin improves insulin sensitivity and protects against obesity associated hyperinsulinemia and hepatosteastosis [11]

Few studies have investigated the role of adropin in some of the high risk pregnancy conditions such as Intrauterine Growth Retardation (IUGR) and gestational diabetes mellitus. However its role in preeclampsia is still unclear. Contra verse studies showed alterations of serum adropin in pregnant women with preeclampsia; Wang et al., [12] revealed for the first time that in preeclampsia serum adropin levels were higher comparing to that of women with normal pregnancy. In contrast, maternal and umbilical cord adropin levels were significantly lower in the preeclamptic women compared to controls [13]

On the previous data, this study was established to investigate serum levels of adropin in L-NAME preeclampsia-like rat model with and without treatment with Sildenafil citrate, furthermore, to assess the associations between adropin with some metabolic, inflammatory and oxidative stress parameters in these models.

\section{Material and Methods}

From 12 th December 2017 to 30 th June 2018 , this study was carried out on healthy adult albino rats (45 female weighing 180-200g, 15 male weighting $190-220 \mathrm{~g})$. They were housed in steel wire cages ( 6 cages) at the Animal House in Faculty of Medicine of Zagazig University under hygienic conditions. They were fed standard chow, had free access to water, kept at comfortable temperature (20 to $24^{\circ} \mathrm{C}$ ) and were maintained on a $12 \mathrm{~h}$ light/ dark cycle. The rats were accommodated to animal house conditions for one week before the experiments going on. The experimental protocol was approved by physiology department and by Local Medical Ethics Committee in Faculty of Medicine of Zagazig University (Institutional Review Board, IRB). Female rats in estrous cycle were mated with male at a ratio of one male to three females.
Females were inspected daily and the day of appearance of a vaginal plug was regarded as day 1 of pregnancy. Out of 45 females, 32 became pregnant and were randomly divided into four groups $(n=8)$ : Control group (pregnant rats were given vehicle (saline) starting from the gestational day 7 to 18 , sildenafil treated group (SIL group), LNAME treated group (L-NAME group) and LNAME + sildenafil group (L-NAME + SIL group). L-NAME (Sigma-Aldrich, St. Louis, MO, USA) was prepared in saline solution and stored in a freezer at $-20^{\circ} \mathrm{C}$. L-NAME and L-NAME + SIL groups received L-NAME subcutaneously $(50 \mathrm{mg} /$ $\mathrm{kg} / \mathrm{day}$ ), from day 7 to day 18 of gestation to induce pre-eclampsia like symptoms. The sildenafil solution was prepared by grinding Viagra tablets (Pfizer Inc., New York, NY, USA) into powder and dissolving in distilled water. SIL and LNAME-SIL groups received sildenafil citrate orally $(10 \mathrm{mg} /$ $\mathrm{kg} /$ day) from day 8 to day 18 of gestation $[6,14]$.

\section{Determination of the first day of pregnancy:}

Vaginal smears taken from the female rats were examined daily by using light microscope to ensure that they were in regular estrus cycle. The estrus phase of the estrus cycle was detected by the presence of cornified epithelial cells which increase in number and eventually predominate as the estrus progresses [15]. The female proved to be in estrus phase was paired with a mature male rat in a separate cage. After mating, females were subsequently isolated until the time of analysis to ensure accurate gestation timing, and in the next morning a vaginal smear taken. Presence of a copulation plug or spermatozoa in the vagina indicated the first day of gestation [16].

Calculating BMI index: Each rat was put in closed plastic container and was weighed on gestational day 1 and 19; body length was taken as the distance from the nose tip to the anus. BMI were calculated, BMI equals body weight (gm)/ length ${ }^{2}\left(\mathrm{~cm}^{2}\right)[17]$.

Urine collection: On day 18 of pregnancy, rats were housed separately in metabolic cages for 24hour urine collection. Urine samples were collected, measured for volume and centrifuged 10 minutes at approximately $3000 \mathrm{rpm}$ to remove insoluble materials. The supernatant was kept at $-20^{\circ} \mathrm{C}$. Total proteins: Were assayed using Urinary Protein Assay Kit (Chondrex, Inc. 2607-151 place NE Redmond, WA 98052, USA) as described by Nishi and Elin [18].

Measurement of blood pressure: On day 19 of gestation, Systolic and diastolic blood pressures 
were measured using a tail-cuff method (NIBP 250, Serial No: 21202-108, BIOPAC system, Inc.; USA). Three measurements with 30 second intervals were recorded and the average of these readings was calculated followed by calculation of the Mean Arterial blood Pressure (MAP) [19]

Sample collection and morphometric analysis: Rats were sacrificed at day 19 of gestation by decapitation under light halothane anesthesia. A laparotomy was performed to expose the uterine horns. The number of developed fetuses and their respective placenta in the right uterine horn were counted, removed and weighed on an electronic balance with a least count of $0.001 \mathrm{~g}$ [6].

Preparation of placenta homogenates: The placenta of right uterine horn were sliced, placental tissue were perfused with a PBS (phosphate buffered saline) solution, $\mathrm{pH} 7.4$ containing $0.16 \mathrm{mg}$ $\mathrm{mL}^{-} 1$ to remove any red blood cells and clots. Then, they were homogenized in $5-10 \mathrm{~mL}$ cold buffer. The homogenate was centrifuged at 10,000 $\mathrm{rpm}$ for $15 \mathrm{~min}$ at $4^{\circ} \mathrm{C}$. Supernatant was taken as sample for investigation. The values of parameters are expressed per milligram or gram of tissue protein [20]

Placental antioxidant system evaluation: Assay of Superoxide Dismutase (SOD) activity according to the method of Kakkar et al., [21] Glutathione Peroxidase (GPX) activity: According to the method of Reddy et al., [22] and assay of Malondialdehyde (MDA) level: According to the method of Ohkawa et al., [23]. All are measured by using spectrophotometer (spectronic 3000 Array, Germany) at 560, 430 and $535 \mathrm{~nm}$ respectively.

Histopathological studies: The left uterine horn was rapidly removed and the specimens of the placentae were rapidly fixed in $10 \%$ formal saline for 48 hours and then washed by tap water. Placental specimens then were processed for paraffin sections. Some sections were cut, mounted on glass slides and stained with hematoxylin and eosin $(\mathrm{H}$ $\&$ E) for the histological examination [24] .

Blood sampling: Blood was collected in clean plastic centrifuge tubes and left to clot. Serum was separated by centrifugation of blood at 3000rpm for 15 minutes and stored frozen at $-20^{\circ} \mathrm{C}$ until used.

Serum analysis for the following: Urea levels according to Tietz [25] by using rat kits for urea level estimation (Spinreact, S.A.U. ctra. Santa Coloma, 7e-17176 Santesteve de bas (gi), Spain), creatinine levels according to Jaffe [26] using rat kits for creatinine level estimation (Spinreact, S.A.U. ctra. Santa Coloma, 7e-17176 Santesteve de bas (gi), Spain), insulin levels according to Temple et al., [27] using KAP1251-INS-EASIA (Enzyme Amplified Sensitivity Immunoassay) kits (BioSource Europe S.A., Belgium). Glucose levels according to Tietz [25] using glucose enzymatic (GOD-PAP)-liquizyme rat Kits (Biotechnology, Egypt). Calculation of homeostatic model assessment of insulin resistance index (HOMA-IR) based on serum insulin level ( $\mathrm{U} / \mathrm{ml}$ ) and serum glucose level $(\mathrm{mg} / \mathrm{dl})$ according to the formula described by Matthews et al., [28] as HOMA-IR = Fasting serum glucose $(\mathrm{mg} / \mathrm{dl}) \mathrm{X}$ fasting serum insulin (U/al) /405. Total Cholesterol (TC) levels according to Tietz [25] by using total cholesterol kits estimation (BioSource Europe S.A). High Density Lipoproteins (HDL-c) levels according to Nauk et al., [29] by using kits for HDL-cholesterol (BioSource Europe S.A). Low Density Lipoproteins (LDL-c) calculated according to Friedewald et al. [30], LDL=TC-HDL-TG/5. Total triglycerides (TG) levels according to Naito [31] using triglycerides ESPAS SL kits A (Elttech S.A., Lyon, France). C Reactive Proteins (CRP) levels according to Ridker et al., [32] using CRP Kits (Monobind Inc Lake Forest, Ca 92630, USA), endothelin-1 levels using endothelin-1 Enzyme Immunoassay Kit, (EIA kit, Cayman, USA, Cat No., 583151) according to manufacture's instructions, and adropin levels using rat adropin ELISA enzyme-linked immunoassay kits (Sun Red Biotechnology, China catalogue No 201-11-3361) according to manufacture's instructions.

Statistical analysis: Results were presented as mean \pm Standard Deviation (SD). Statistical analysis was performed using the Statistical Package for the Social Sciences (SPSS), Version 20.0 (SPSS Inc., Chicago, IL, United States). Repeated measures of analysis of variance (ANOVA) were applied followed by the Student-Least Significant Deference (LSD), post hoc test to compare means of each two different groups. Pearson's correlation analysis was performed to screen potential relations between serum levels of Adropin and all measured parameters. For all statistical tests done, $p$-value $<0.05$ was considered to be statistically significant.

\section{Results}

Regarding (Table 1) \& Figs. (1-4): No statistically significant differences were noted between control and SIL groups in all measured parameters $(p>0.05)$, LNAME preeclampsia rats revealed significant reduction in the mean values of final BMI $\left(0.53 \pm 0.06 \mathrm{gm} / \mathrm{Cm}^{2}\right)$, placental weights $(0.47 \pm$ 
$0.05 \mathrm{~g})$ and fetal weights $(3.81 \pm 0.57 \mathrm{~g})$ in comparison to those of control group $(0.65 \pm 0.04,0.57 \pm 0.03$ and 5.36 \pm 0.62 respectively, $p<0.001)$, SIL group $(0.64 \pm 0.04,0.58 \pm 0.05$, and $5.39 \pm 0.53$ respectively, $p<0.001)$, and L NAME + SIL group $(0.59 \pm 0.02$, $0.52 \pm 0.03$ and $4.63 \pm 0.6$ respectively, $p<0.05$, $p<0.05$ and $p<0.001$ respectively). Moreover, LNAME preeclampsia rats presented significant increase in the mean values of MAP $(121.65 \pm 11.4$ $\mathrm{mmHg})$ and urinary total proteins $(50.75 \pm 7.21 \mathrm{mg})$ as compared to control $(80.5 \pm 7.18$ and $17.62 \pm 2.74$ respectively) ( $p<0.001)$, SIL $(81.75 \pm 6.79$ and $16.34 \pm 2.62$ respectively, $p<0.001)$ and L NAME + SIL group $(90.56 \pm 11.37$ and $22.83 \pm 4.7$ respectively, $p<0.01, p<0.001)$.

Regarding serum biochemical parameters, there was significant increase in the mean values of serum urea $(40.61 \pm 7.63 \mathrm{mg} / \mathrm{dl})$, creatinine $(0.44 \pm$ $0.07 \mathrm{mg} / \mathrm{dl}), \mathrm{CRP}(1.36 \pm 0.14 \mathrm{Ug} / \mathrm{ml})$, endothelin- 1 $(2.85 \pm 0.24 \mathrm{pg} / \mathrm{ml})$, TGs $(110.72 \pm 10.58 \mathrm{mg} / \mathrm{dl}), \mathrm{TC}$
$(162.7 \pm 12.76 \mathrm{mg} / \mathrm{dl}), \mathrm{LDL}-\mathrm{c}(99.26 \pm 9.85 \mathrm{mg} / \mathrm{dl})$, glucose $(117.98 \pm 4.78 \mathrm{mg} / \mathrm{dl})$, insulin $(17.86 \pm 2.16$ $\mathrm{uIU} / \mathrm{mL})$, HOMA-IR $(5.59 \pm 0.45)$ and serum adropin levels $(60.22 \pm 6.28 \mathrm{ng} / \mathrm{ml})$ in LNAME preeclampsia rats in contrast to those in control group $(21.21 \pm 2.70,0.21 \pm .048,0.77 \pm 0.09,1.54 \pm 0.17$, $69.37 \pm 6.03,110.22 \pm 8.37,55.98 \pm 3.37,91.98 \pm 7.87$, $8.06 \pm 2.11,1.80 \pm 0.17$ and $32.47 \pm 4.03$ respectively, $p<0.001)$, SIL group $(18.64 \pm 1.39,0.20 \pm 0.03,0.75 \pm$ $0.07,1.45 \pm 0.15,68.38 \pm 7.79,106.76 \pm 11.48,55.31 \pm$ $7.28,92.25 \pm 7.45,7.92 \pm 1.89,1.79 \pm 0.19$ and $31.46 \pm$ 3.76 respectively, $p<0.001)$ and L NAME + SIL group $(27 \pm 6.3,0.26 \pm 0.05,0.92 \pm 0.09,1.96 \pm 0.12$, $79 \pm 7.81,123.31 \pm 9.55,65.98 \pm 12.3,100.19 \pm 5.26$, $11.43 \pm 1.13,2.59 \pm 0.64$ and $38.18 \pm 4.44$, respectively; $p<0.001)$. However, LNAME preeclampsia rats showed significant decrease in the mean values of serum HDL-c levels $(39.5 \pm 6.06 \mathrm{mg} / \mathrm{dl})$ versus the corresponding levels in control (58.36 \pm 8.57 , $p<0.001)$, SIL group $(60.47 \pm 3.64, p<0.001)$ and L NAME + SIL group $(50.42 \pm 6.07, p<0.01)$.

Table (1): Statistical analysis of maternal BMI $\left(\mathrm{gm} / \mathrm{Cm}^{2}\right.$ ), placental weight (g), fetal weight (g), MAP (mmHg), urinary proteins $(\mathrm{mg} / 24 \mathrm{~h})$ and all serum parameters of the studied groups.

\begin{tabular}{|c|c|c|c|c|}
\hline $\mathrm{N}=8$ & Control & SIL & LNAME & L NAME + SIL \\
\hline BMI (gestational 1) & $0.52 \pm 0.03$ & $0.53 \pm 0.01$ & $0.52 \pm 0.02$ & $0.52 \pm 0.05$ \\
\hline final BMI $\left(\mathrm{gm} / \mathrm{Cm}^{2}\right)$ & $0.65 \pm 0.04$ & $0.64 \pm 0.04 \mathrm{NSa}$ & $0.53 \pm 0.06, p<0.001$ a,b & $0.59 \pm 0.02, p<0.05^{\mathbf{a}} \mathbf{b}^{\prime} \mathbf{c} \mathbf{c}$ \\
\hline Placental weight (g) & $0.57 \pm 0.03$ & $0.58 \pm 0.05 \mathrm{NS}^{\mathbf{a}}$ & $0.47 \pm 0.05, p<0.001 \mathbf{a , b}$ & $0.52 \pm 0.03, p<0.05^{\mathbf{a}} \mathbf{b}{ }^{\prime} \mathbf{c}$ \\
\hline Fetal weight $(\mathrm{g})$ & $5.36 \pm 0.62$ & $5.39 \pm 0.53 \mathrm{NS}^{\mathbf{a}}$ & $3.81 \pm 0.57, p<0.001$ a,b & $4.63 \pm 0.6, p<0.05^{\mathbf{a}^{\mathbf{a}} \mathbf{b}}, p<0.001^{\mathbf{c}}$ \\
\hline MAP $(\mathrm{mmHg})$ & $80.5 \pm 7.18$ & $81.75 \pm 6.79 \mathrm{NSa}$ & $121.65 \pm 11.4, p<0.001$ a,b & $90.56 \pm 11.37, p<0.05^{\mathbf{a}} \mathbf{b} \mathbf{b}, p<0.001 \mathbf{c}$ \\
\hline Urea (mg/dl) & $21.21 \pm 2.70$ & $18.64 \pm 1.39 \mathrm{NSa}$ & $40.61 \pm 7.63, p<0.001 \mathbf{a , b}$ & $27 \pm 6.3, p<0.05^{\mathbf{a}}, p<0.01^{\mathbf{b}}, p<0.001^{\mathbf{c}}$ \\
\hline Creatinine $(\mathrm{mg} / \mathrm{dl})$ & $0.21 \pm .048$ & $0.20 \pm 0.03 \mathrm{NS}^{\mathbf{a}}$ & $0.44 \pm 0.07, p^{<0.001} \mathbf{a}, \mathbf{b}$ & $0.26 \pm 0.05, p^{<0.05^{\mathrm{a}} \mathbf{b}}, \mathrm{p}<0.001^{\mathbf{c}}$ \\
\hline Total urinary proteins $(\mathrm{mg} / 24 \mathrm{~h})$ & $17.62 \pm 2.74$ & $16.34 \pm 2.62 \mathrm{NSa}$ & $50.75 \pm 7.21, p<0.001$ a,b & $22.83 \pm 4.7, p<0.05^{\mathbf{a}} \mathbf{b}, p<0.001^{\mathbf{c}}$ \\
\hline $\mathrm{TG}(\mathrm{mg} / \mathrm{dl})$ & $69.37 \pm 6.03$ & $68.38 \pm 7.79 \mathrm{NSa}$ & $110.72 \pm 10.58, p^{<0.001^{\mathbf{a}} \mathbf{b}}$ & $79 \pm 7.81, p<0.05^{\mathbf{a}} \mathbf{b}, p<0.001^{\mathbf{c}}$ \\
\hline $\mathrm{TC}(\mathrm{mg} / \mathrm{dl})$ & $110.22 \pm 8.37$ & $106.76 \pm 11.48 \mathrm{NS}^{\mathbf{a}}$ & $162.7 \pm 12.76, p<0.001 \mathbf{a , b}$ & $123.31 \pm 9.55, p<0.05^{\mathbf{a}}, p<0.01^{\mathbf{b}}, p<0.001^{\mathbf{c}}$ \\
\hline LDL-c (mg/dl) & $55.98 \pm 3.37$ & $55.31 \pm 7.28 \mathrm{NS}^{\mathbf{a}}$ & $99.26 \pm 9.85, p<0.001 \mathbf{a , b}$ & $65.98 \pm 12.3, p<0.05^{\mathbf{a}^{\prime} \mathbf{b}}, p<0.001 \mathbf{c}$ \\
\hline HDL-c (mg/dl) & $58.36 \pm 8.57$ & $60.47 \pm 3.64 \mathrm{NSa}$ & $39.5 \pm 6.06 p<0.001$ a,b & $50.42 \pm 6.07, p<0.05 \mathrm{a}, p<0.01 \mathbf{b}^{\mathbf{b}} \mathbf{c}$ \\
\hline Glucose (mg/dL) & $91.98 \pm 7.87$ & $92.25 \pm 7.45 \mathrm{NSa}$ & $117.98 \pm 4.78, p<0.001 \mathbf{a , b}$ & $100.19 \pm 5.26, p<0.05^{\mathbf{a}} \mathbf{b}, p<0.001^{\mathbf{c}}$ \\
\hline Insulin (uIU/mL) & $8.06 \pm 2.11$ & $7.92 \pm 1.89 \mathrm{NS}^{\mathrm{a}}$ & $17.86 \pm 2.16, p<0.001^{\mathbf{a}, \mathbf{b}}$ & $11.43 \pm 1.13, p<0.01^{\mathbf{a}} \mathbf{b}, p<0.001^{\mathbf{c}}$ \\
\hline HOMA-IR & $1.80 \pm 0.17$ & $1.79 \pm 0.19 \mathrm{NS} \mathbf{a}$ & $5.59 \pm 0.45, p^{<0.001} \mathbf{a , b}$ & $2.59 \pm 0.64, p<0.01^{\mathbf{a}} \mathbf{b}, p<0.001 \mathbf{c}$ \\
\hline $\mathrm{CRP}(\mathrm{Ug} / \mathrm{ml})$ & $0.77 \pm 0.09$ & $0.75 \pm 0.07 \mathrm{NSa}$ & $1.36 \pm 0.14, p<0.01$ a,b & $0.92 \pm 0.09, p<0.01^{\mathbf{a}} \mathbf{b}, p<0.001^{\mathbf{c}}$ \\
\hline Placental MDA (nmc & $31.9 \pm 2.5$ & $31.2 \pm 2.5 \mathrm{NS} \mathbf{a}^{\mathbf{a}}$ & $55.65 \pm 6.35, p<0.001 \mathbf{a , b}$ & $37.02 \pm 4.5, p<0.05^{\mathbf{a}} \mathbf{b}, p<0.001^{\mathbf{c}}$ \\
\hline Placental SOD (U/mg protein) & $10.16 \pm 1.6$ & $10.46 \pm 0.69 \mathrm{NSa}$ & $6.26 \pm 1.87, p<0.001^{\mathbf{a}, \mathbf{b}}$ & $8.64 \pm 1.45, p<0.05^{\mathbf{a} \cdot \mathbf{b}}{ }_{i} p<0.001^{\mathbf{c}}$ \\
\hline $\begin{array}{l}\text { Placental GSH-Px levels } \\
\text { (U/mg protein) }\end{array}$ & $13.73 \pm 1.78$ & $13.95 \pm 1.41 \mathrm{NS} \mathbf{a}^{\mathbf{a}}$ & $9.68 \pm 2.08, p<0.001 \mathbf{a , b}$ & $11.92 \pm 1.27, p<0.05 \mathbf{a}^{\prime} \mathbf{b}^{\prime} \mathbf{c}$ \\
\hline Endothelin-1 (pg/ml) & $1.54 \pm 0.17$ & $1.45 \pm 0.15 \mathrm{NS}^{\mathbf{a}}$ & $2.85 \pm 0.24, p<0.001 \mathbf{a , b}$ & $1.96 \pm 0.12, p<0.01^{\mathbf{a}} \mathbf{b}, p<0.001 \mathbf{c}$ \\
\hline Adropin (ng/ml) & $32.47 \pm 4.03$ & $31.46 \pm 3.76 \mathrm{NSa}$ & $60.22 \pm 6.28, p<0.001 \mathbf{a , b}$ & $38.18 \pm 4.44, p<0.05^{\mathbf{a}}, p<0.01^{\mathbf{b}}, p<0.001^{\mathbf{c}}$ \\
\hline
\end{tabular}

NS: No Significant $(p>0.05)$.

a : $p$-value of significance versus control group.

$b: p$-value of significance versus SIL group.

$c: p$-value of significance versus LNAME group.

Concerning placental tissue oxidative activities, there was significant increase in the mean values of placental MDA levels $(55.65 \pm 6.35 \mathrm{nmol} / \mathrm{gm}$ tissue) in LNAME preeclampsia rats in contrast to those in control group $(31.9 \pm 2.5, p<0.001)$, SIL group $(31.2 \pm 2.5, p<0.001)$ and L NAME + SIL group $(37.02 \pm 4.5, p<0.001)$, while there was significant decrease in the mean values of placental SOD $(6.26 \pm 1.87 \mathrm{U} / \mathrm{mg}$ protein) and GSH-Px levels $(9.68 \pm 2.08 \mathrm{U} / \mathrm{mg}$ protein) as compared to those in control $(10.16 \pm 1.6,13.73 \pm 1.78$ respectively, $p<0.001)$, SIL group $(10.46 \pm 0.69,13.95 \pm 1.41$ respectively, $p<0.001)$ and L NAME + SIL group $(8.64 \pm 1.45,11.92 \pm 1.27$ respectively. Concerning (Table 2); serum adropin levels in LNAME preeclampsia rats and in L NAME + SIL group showed significant positive correlations with each of following; MAP ( $r=0.838, p<0.01 ; r=0.849, p<0.01$ respectively), total urinary proteins levels ( $r=0.842$, $p<0.01 ; r=0.789, p<0.05$ respectively), serum levels of; urea $(r=0.791, p<0.05 ; r=0.808, p<0.05$ respectively), creatinine ( $r=0.830, p<0.05 ; r=0.860$, 
$p<0.05$ respectively), CRP ( $r=0.765, p<0.05 ; r=$ $0.795, p<0.05$ respectively), endothelin- 1 ( $r=0.773$, $p<0.05 ; r=0.939, p<0.01$ respectively), TGs ( $r=$ $0.814, p<0.05 ; r=0.828, p<0.05$ respectively), TC ( $r=0.898, p<0.01 ; r=0.934, p<0.01$ respectively), LDL-c $(r=0.900, p<0.01 ; r=0.891, p<0.01$ respectively), glucose $(r=0.906, p<0.01 ; r=0.961, p<0.001$ respectively), insulin ( $r=0.917, p<0.01 ; r=0.950$, $p<0.001$ respectively), HOMA-IR ( $r=0.943$, $p<0.001 ; r=0.816, p<0.05$ respectively) and Placental tissue MDA levels ( $r=0.993, p>0.001$; $r=0.912, p<0.01$ respectively), however, they revealed significant negative correlation with maternal BMI ( $r=-0.848, p<0.01 ; r=-0.889, p<0.01$ respectively), placental weights ( $r=-0.767, p<0.05$; $r=-0.881, p<0.01$ respectively), fetal weights ( $r=$
$0.874, p<0.01 ; r=0.765, p<0.05$ respectively), serum HDL-c levels ( $r=-0.763, p<0.05 ; r=-0.920$, $p<0.01$ respectively), placental SOD tissue levels $(r=-0.854, p<0.01 ; r=-0.780, p<0.05$ respectively) and placental GSH tissue levels ( $r=-0.890, p<0.01$; $r=-0.839, p<0.01$ respectively).

Additionally, in controls and SIL groups, significant correlations were found between adropin and MAP $(r=0.742, p<0.05 ; r=0.818, p<0.05$ respectively), endothelin-1 ( $r=0.768, p<0.05 ; r=$ $0.862, p<0.01$ respectively), while negative correlations with TGs levels ( $r=-0.730, p<0.05 ; r=$ $-0.842, p<0.01$ respectively). Control group showed positive significant correlations between adropin and HDL-c $(r=0.756, p<0.05)$.

Table (2): Pearson's correlation analysis between serum adropin and all other parameters in studied groups.

\begin{tabular}{|c|c|c|c|c|c|c|c|c|}
\hline & \multicolumn{2}{|c|}{ Control } & \multicolumn{2}{|c|}{ SIL } & \multicolumn{2}{|c|}{ LNAME } & \multicolumn{2}{|c|}{ L NAME + SIL } \\
\hline & $r$ & $p$-value & $r$ & $p$-value & $r$ & $p$-value & $r$ & $p$-value \\
\hline Maternal BMI & -0.695 & 0.056 & -0.260 & 0.535 & -0.848 & $0.008 * *$ & -0.889 & $0.003 * *$ \\
\hline Placental weight (g) & -0.595 & 0.120 & -0.588 & 0.126 & -0.767 & $0.026^{*}$ & -0.881 & $0.004 * *$ \\
\hline Fetal weight (g) & -0.408 & 0.316 & -0.103 & 0.808 & -0.874 & $0.005 * *$ & -0.765 & $0.027 *$ \\
\hline MAP (mmHg) & 0.742 & $0.035^{*}$ & 0.818 & $0.013^{*}$ & 0.838 & $0.009 * *$ & 0.849 & $0.008 * *$ \\
\hline Urea (mg/dl) & 0.263 & 0.529 & 0.391 & 0.388 & 0.791 & $.019^{*}$ & 0.808 & $0.015^{*}$ \\
\hline Creatinine (mg/dl) & 0.204 & 0.628 & 0.253 & 0.545 & 0.830 & $0.011^{*}$ & 0.860 & $0.006^{* *}$ \\
\hline urinary proteins $(\mathrm{mg} / 24 \mathrm{~h})$ & 0.433 & 0.284 & 0.448 & 0.266 & 0.842 & $0.009 * *$ & 0.789 & $0.020 *$ \\
\hline $\mathrm{CRP}(\mathrm{Ug} / \mathrm{ml})$ & 0.666 & 0.071 & 0.256 & 0.451 & 0.765 & $0.027 *$ & 0.795 & $0.018^{*}$ \\
\hline Endothelin-1 (pg/ml) & 0.768 & $0.026^{*}$ & 0.862 & $0.006^{* *}$ & 0.773 & $0.024^{*}$ & 0.939 & $0.001 * *$ \\
\hline Placental MDA (nmol/gm tissue) & 0.252 & 0.547 & 0.109 & 0.798 & 0.993 & $>0.001 * * *$ & 0.912 & $0.002 * *$ \\
\hline Placental SOD (U/mg protein & 0.527 & 0.179 & -0.354 & 0.390 & -0.854 & $0.007 * *$ & -0.780 & $0.022 *$ \\
\hline Placental GSH-Px (U/mg protein) & -0.139 & 0.743 & 0.105 & 0.804 & -0.890 & $0.003 * *$ & -0.839 & $0.009 * *$ \\
\hline Glucose (mg/dl) & 0.123 & 0.702 & 0.230 & 0.461 & 0.906 & $0.002 * *$ & 0.961 & $>0.001 * * *$ \\
\hline Insulin (uIU/mL) & 0.656 & 0.077 & 0.621 & 0.082 & 0.917 & $0.001 * *$ & 0.950 & $>0.001 * * *$ \\
\hline HOMA-IR & 0.467 & 0.302 & 0.104 & 0.802 & 0.943 & $>0.001 * * *$ & 0.816 & $0.014^{*}$ \\
\hline $\mathrm{TG}(\mathrm{mg} / \mathrm{dl})$ & -0.730 & $0.040^{*}$ & -0.842 & $0.009 * *$ & 0.814 & $0.014^{*}$ & 0.828 & $0.011^{*}$ \\
\hline $\mathrm{TC}(\mathrm{mg} / \mathrm{dl})$ & -0.419 & 0.302 & -0.576 & 0.135 & 0.898 & $0.002 * *$ & 0.934 & $0.001 * *$ \\
\hline LDL-c (mg/dl & -0.064 & 0.881 & -0.015 & 0.973 & 0.900 & $0.002 * *$ & 0.891 & $0.003 * *$ \\
\hline HDL-c (mg/dl) & 0.756 & $0.030^{*}$ & 0.299 & 0.472 & -0.763 & $0.028 *$ & -0.920 & $0.001 * *$ \\
\hline
\end{tabular}

*: Significant $(p<0.05)$.

$* *$ : Highly significant $(p<0.001)$

$r$ : Correlation coefficient.

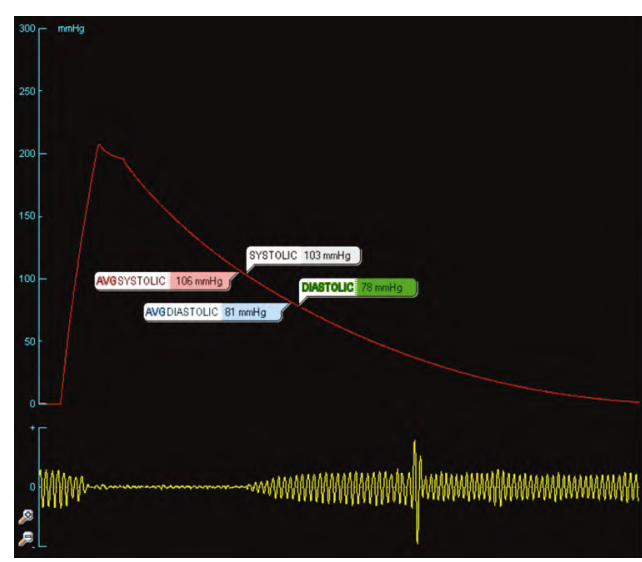

Fig. (1): Recorded blood pressure from control group.

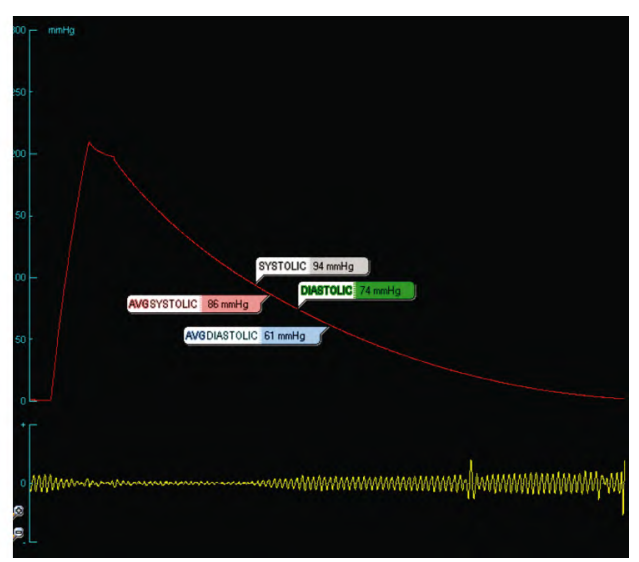

Fig. (2): Recorded blood pressure from SIL group. 




Fig. (3): Recorded blood pressure from L-NAME group.

\section{Histopathological results:}

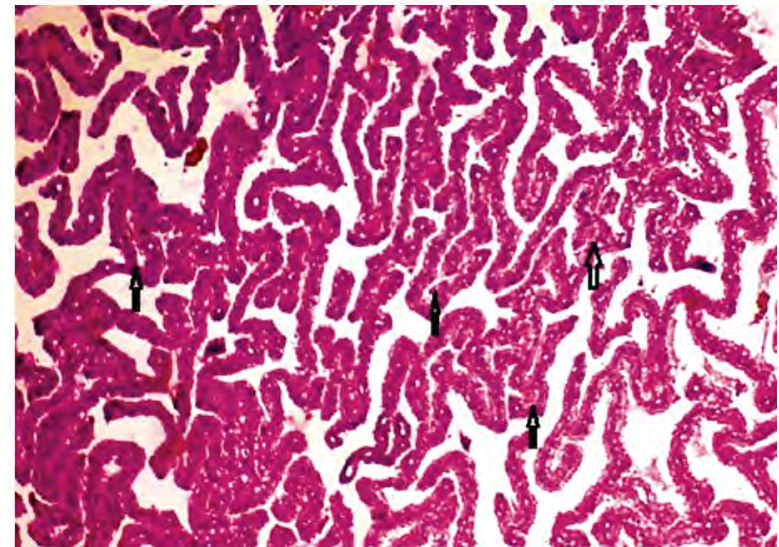

Photo (1): Photomicrograph of placental section from control rats showing normal placental tissue of normalsized chorionic villi lined by cytotrophoblastic cells (Ò) (H \& E X400).

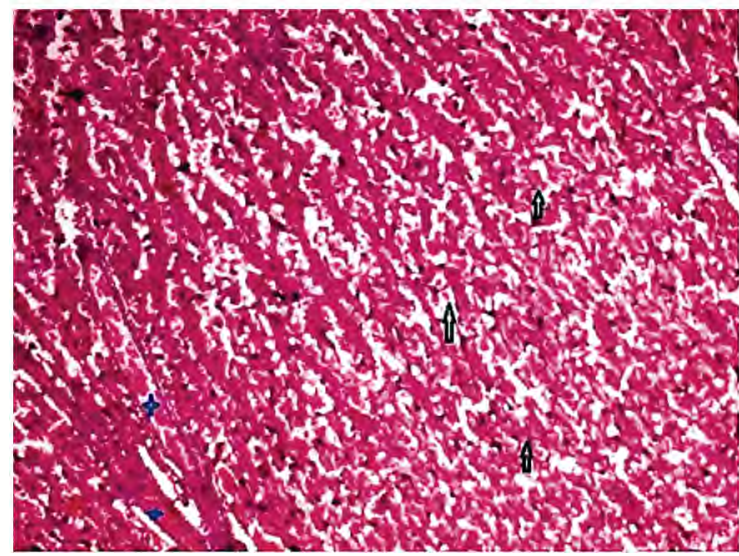

Photo (3): Photomicrograph of placental tissue from LNAME preeclampsia group showing; large areas of necrosis (Ò) infiltrated by aggregates of inflammatory cells. The blood vessels are dilated and thrombosed (TM) (H \& E X400).



Fig. (4): Recorded blood pressure from L-NAME + SIL group.



Photo (2): Photomicrograph of placental section from SIL treated rats showing normal placental tissue of normal-sized chorionic villi lined by cytotrophoblastic cells (Ò) (H \& E X400).

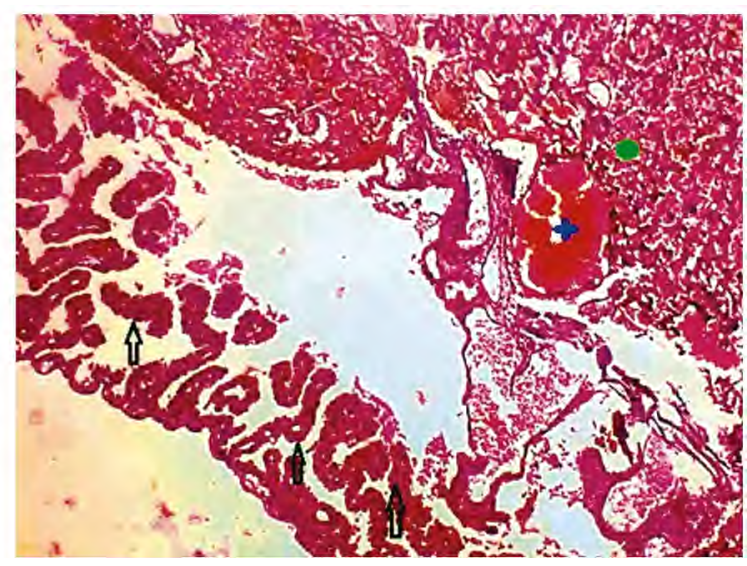

Photo (4): Photomicrograph of placental section from LNAME + SIL group Showing areas of normal-sized chorionic villi lined by cytotrophoblastic cells (Ò) with dilated vascular spaces (TM) surrounded by small areas of necrosis and inflammation () (H \& E E $\mathrm{X} 400$ ). 


\section{Discussion}

In this study, experimental preeclampsia model induced by L-NAME were successfully established and proved by maternal hypertension, proteinuria, increased serum levels of urea and creatinine, besides decreased placental and fetal weights, these findings were consistent with other reports of Zhou et al., [33] and Amaral et al., [34]. Moreover, the histopathological findings were agreed with Powe et al., [35].

L-NAME was found to be a potent competitive NOS inhibitor with subsequently decreasing NO synthesis [36]. This leads to increasing the adhesion molecules expression with subsequent acceleration of the inflammation in systemic vasculature and placenta (which indicated in the current work by increased CRP) and causing endothelial dysfunction with utero-placental perfusion failure [37]. In the kidney, vascular endothelial dysfunction leads to altered renal hemodynamics and reduced renal excretory function causing hypertension and proteinuria [38]. Moreover, increase in ET-1 may be attributed to the reduction in $\mathrm{NO}$ synthesis as $\mathrm{NO}$ was known to be a potent inhibitor of ET-1 production [39]. Additionally, Sandrim et al., [40] revealed that NO synthesis was inversely related to the serum levels of anti-angiogenic factors including soluble endoglin (sEng), soluble fmslike tyrosine kinase-1 (sFlt-1). So, inhibition of NO synthesis will be associated with an increase in these anti-angiogenic factors that inhibit the angiogenic factors; Vascular Endothelial Growth Factor (VEGF), Placental Growth Factor (PIGF), so these factors were strongly incriminated in the pathophysiology of PE and promotes the development of hypertension $[41,42]$. In addition to its $\mathrm{NO}$ inhibitory effect, L-NAME was found to decrease prostacyclin and increase the plasma endothelin and thromboxane $\mathrm{A} 2$ with more vasoconstriction, oxidative stress and hypertension [43]

In current study, rats with preeclampsia showed significant decrease in their BMI on gestational day 18 , placental and fetal weights, these results are similar with Ma et al., [44] and Huai et al., [14], however, Ramesar et al., [45] and Motta et al., [6] found decrease in placental weights but not fetal weights in the same model, L-NAME induces a reduction in $\mathrm{NO}$ in fetal trophoblast vascular area and consequently decreases placental blood flow and fetal oxygen supply, which could be causing IUGR [6]. NOS inhibitors reduce food intake and body weight gain via affecting serotonin metabolism in the cortex, diencephalon causing anorexic effect $[46,47]$
Increased serum glucose, insulin levels and HOMA-IR in rats with preeclampsia in this work suggested development of insulin resistance. Insulin resistance is well established to be associated with preeclampsia in animal $[\mathbf{4 8 , 4 9 ]}$ and human studies [50,51], blockade of NOS causes peripheral insulin resistance secondary to blockade of the hepatic parasympathetic reflex release of hepatic insulinsensitizing substance in response to insulin [52] Also, Oxidative stress and inflammation has been suggested to contribute to insulin resistance

It is clearly seen that L-NAME administration to pregnant rats exhibited placental tissue oxidative damage (increased MDA and reduced activities of the antioxidant enzymes SOD and GSH), inflammation (increased CRP), dyslipidemia (increased TC, LDL-cholesterol and TGs but significant decreased in HDL-cholesterol) and these findings were supported by Ma et al., [44] and Huai et al., [14] who found increased in TC, TGs and free fatty acid levels in LNAME preeclampsia-like mice. In the L-NAME model, the free fatty acid oxidation disorders occur, with decreased levels of mRNA and protein expression of long-chain 3 - hydroxyacyl-CoA dehydrogenase (LCHAD), FFA levels were negatively correlated with LCHAD levels [54]. Oxidative stress has been implicated in the pathophysiology of preeclapmsia because it damages the maternal vascular endothelium as reported by human $[\mathbf{3 4 , 5 5 , 5 6 ]}$ and animal studies $[\mathbf{5 7 , 5 8}$.

In rats received sildenafil only, no alterations in maternal BMI, fetal and placental weights, and MAP and biochemical parameters versus control. These data are similar to studies recorded by Sasser and Baylis [59] and Motta et al., [6] who revealed that use of sildenafil in rats with normal gestation did not induce any change in fetal number or growth. Sildenafil in women with IUGR produced no adverse maternal side effects [60]. It may mediated endothelial relaxation of uterine vessels and improves uterine blood flow via NO-cGMP pathway [61]. Whereas, in LNAME plus Sildenafil treated rats, sildenafil counteracted the effect of L-NAME and improved placental weights and fetal growth and these results were agreed with Dastjerdi et al., [62] who showed that sildenafil used as a therapeutic agent may improve myometrial perfusion in foetal growth restriction pregnancies, Ramesar et al., [63] proved that sildenafil citrate improves uterine artery blood flow and endometrial development in women undergoing in vitro fertilization. 
Moreover, in the current work, Sildenafil had beneficial effects in decreasing the severity of PE by ameliorating the MAP, renal functions, oxidative stress and insulin resistance. And these results were supported by Gillis et al., [64] who showed that Sildenafil improved renal function, reduced MAP, and increased fetal growth in preeclamptic Dahl salt sensitive rats, Sildenafil also enhances preeclampsia symptoms in LNAME and in reduced uterine perfusion pressure models $[45,65]$. Additionally, sildenafil improves fetal growth and maternal blood pressure in human subjects with preeclampsia [35]. Interestingly, chronic treatment with sildenafil improved insulin action and diminished obesity in high-fat-fed mice [66]

Regarding serum adropin levels, rats with preeclampsia showed significantly increase in adropin levels when compared to both control and SIL groups and these levels were positively correlated with MAP, proteinuria, serum levels of urea, creatinine, endothelin-1, CRP,TGs, TC, LDLcholesterol, glucose, insulin, HOMA-IR and placenta tissue of MDA, however were negatively correlated with maternal BMI, placental tissue of SOD, GSH levels and serum HDL-cholesterol levels while in LNAME+ sildenafil treated group adropin levels were significantly decreased compared to LNAME group, and still correlated with all previous parameters.

These results were in line with Wang et al., [12] who showed that serum adropin levels were significantly increased in women with preeclampsia versus with normal pregnancy, however in contrast with those of Cakmak et al., [13] who found that maternal and umbilical cord adropin levels were significantly lower in the preeclamptic women compared to normal subjects and that maternal levels were much lower in the severe preeclampsia than mild preeclampsia, and maternal adropin levels were negatively correlated with systolic and diastolic blood pressures.

Adropin has been shown to be released in many tissues in rats and is also released by vascular endothelial cells and plays a role in the neovascularization [12]. It was reported that adropin had a protective effect on endothelium by up-regulating endothelial nitric oxide synthase in the endothelium via activation of vascular Endothelial Growth Factor Receptor (EGFR) 2 phosphatidylinositol 3kinase Akt and EGFR 2 extracellular signal regulated kinase $1 / 2$ pathways and promoting endothelial function [9]. Also, Topuz et al., [67] showed low levels of adropin in subjects with the endothelial dysfunction. Gözal et al., [10] demonstrated that adropin concentration is reduced in children with obstructive sleep apnea and endothelial dysfunction.

Adropin plays a role in hypertension via endothelial dysfunction [68]. Gu et al., [69] found that patients with essential hypertension had lower levels of serum adropin, and serum adropin was inversely correlated with blood endothelin-1, systolic and diastolic blood pressures. Moreover, Gulen et al., [70] found significantly higher levels of adropin in normotensive patients compared to hypertensive ones with and without target organ damage and they reported that adropin was not correlated with systolic and diastolic blood pressure. However, Bolayır et al., [71] showed decreased adropin levels in nocturnal hypertensive and nondipper hypertensive patients and a strong correlation was found between nighttime blood pressure levels with adropin and hsCRP levels. Animal studies indicated that adropin regulates angiogenesis, increases blood flow and capillary density in an ischemia model [9]

It was suggested that increased maternal serum adropin in this study might serve as a protective feedback mechanism against the pathogenesis of preeclampsia: Endothelial dysfunction, insulin resistance, oxidative stress, and inflammation.

It is possibly proper to assume that adropin may be involved in the regulation of fetal growth. In current study, maternal adropin levels were negatively correlated with placental and fetal weights in preeclampsia group and in preeclampsia treated with sildenafil group and these results were agreed by Celik et al., [72] who reported a negative correlation between umbilical cord adropin levels, gestational age at delivery and birth weight in pregnancies complicated with GDM, also Baka et al., [73] showed that maternal serum adropin levels in severe IUGR cases were increased and they explained this increased adropin as a compensatory feedback mechanism to counteract endothelial placental dysfunction in IUGR.

Contrary to these findings, Cakmak et al., [13] found a positive correlation between umbilical cord adropin levels and both birth weight and gestational age at delivery and they assumed that an increased adropin expression may be a representative of normally functioning placenta and consequently healthy fetal maturation, Qui et al., [74] observed a positive correlation between cord blood adropin concentrations and placental weight and gestational age at birth in preterm deliveries. Moreover, Aydin et al., [75] reported decreased 
levels of adropin in both umblical cord and maternal blood in IUGR cases and they identified positive correlations between endothelin and adropin in healthy pregnancies but not in pregnancies with IUGR.

Respect to adropin correlations with glucose metabolism parameters in other studies; serum adropin positively correlated with elevated $\mathrm{HbA} 1$ in gestational diabetes mellitus [76], in contrast, Aydın et al., [75] reported that there was a negative correlation between adropin concentrations and HbA1c (\%), also serum adropin level is inversely associated with glucose and insulin resistance in T2DM patients [77] and in polycystic ovary [78] Kumar et al., [79] showed that increased adropin decrease insulin resistance and glucose intolerance that occur in response to metabolic stress, Gao et al., [80] concluded that adropin improves glucose clearance, ameliorates insulin resistance and reverses dyslipidemia in obese mice, intraperitoneal administration of adropin significantly decreased the levels of fasting blood glucose, HbA1c (\%), HOMA-IR and insulin levels [81] however, no correlations with glucose parameters in End Stage Renal Disease (ESRD) [82], or in essential hypertenstion [69]. Accordingly, it can be speculated that higher adropin in experimental preeclampsia in rats is one of the multiple adaptive responses on adverse glucose metabolism.

Some researchers have noted negative relationships between serum adropin and cholesterol, very low-density lipoprotein cholesterol, and triglyceride in women with polycystic ovary syndrome [78] Moreover, serum adropin levels negatively correlated with triglycerides and BMI in patients with myocardial infarction and those with metabolic syndrome after gastric bypass $[\mathbf{8 3 , 8 4}]$. Akcilar et al., [81] found that administration of adropin significantly decreased inflammatory cytokines, levels of LDL-C and increased the levels of HDL-C in rat model with hyperlipidemia and they suggested that adropin could have a strong anti-hyperlipidemia activity and also ameliorate other lipid metabolism disorder-related complications. In contrast, no associations between adropin and lipid profile in patients with ESRD [82] or amongst young adolescents [85] . Interestingly, control rats in this study revealed negative correlations of adropin with triglycerides and positive with HDL-cholesterol and these observations were recorded by Kalu zna et al., [82], similarly, Nowak et al., [86] detected a positive correlation between adropin level and HDL cholesterol but no correlation with BMI in healthy women. Recently, Yang et al., [87] indicated that adropin levels negatively correlate with mark- ers of oxidative stress injury and endothelial dysfunction in Rat Brain of old age.

\section{Conclusion:}

Increased maternal adropin levels in preeclampsia like model in rats might represent a regulatory feedback mechanism against insulin resistance endothelial placental dysfunction; inflammation and oxidative stress which associated with origin of preeclampsia, hence identify it as a potentially protective agent against preeclampsia development. Sildenafil citrate can alleviate the gestational hypertension and proteinuria and improve the pregnancy outcomes by reducing inflammation insulin resistance and oxidative stress in experimental preeclampsia. Further studies are required in order to have a better understanding of the relation between preeclampsia and adropin.

\section{Acknowledgment:}

To Kamal El-Kashishi, Professor of Pathology, Faculty of Medicine, Zagazig University for performing the histological study.

\section{References}

1- PETLA L.T., CHIKKALA R., RATNAKAR K.S., KODATI and SRITHARAN V.: Biomarkers for the management of pre-eclampsia in pregnant women. Indian J. Med. Res., 138: 60-7, 2013.

2- PHIPPS E., PRASANNA D., BRIMA W. and JIM B.: Preeclampsia: Updates in pathogenesis, definitions, and guidelines, Clin. J. Am. Soc. Nephrol. C.J.A.S.N., 11. 1113-1102 (6), 2016

3- ROBERTS J.M. and HUBEL C.: The two stage model of preeclampsia: Variations on them. Placenta, 30: 1-6, 2009.

4- SELIGMAN S.P., ABRAMSON S.B., YOUNG B.K. and BUYON J.P.: The role of nitric oxide in the pathogenesis of pre-eclampsia. Am. J. Obstet. Gynaecol., 172, pp. 9448, 1994.

5- KHALIL R.A. and GRANGER J.P.: Vascular mechanisms of increased arterial pressure in preeclampsia: Lessons from animal models. Am. J. Physiol. Regul. Integr. Comp. Physiol., 283: R29-R45, 2002.

6- MOTTA C., GROSSO C., ZANUZZI C., MOLINERO D., PICCO N., BELLINGERI R., ALUSTIZA F., BARBEITO C., VIVAS A. and ROMANINI M.C.: Effect of Sildenafil on Pre-Eclampsia-Like Mouse Model Induced By L-Name. Reprod. Domest. Anim., 50 (4): 611-6, 2015.

7- MAHARAJ C.H., O'TOOLE D., LYNCH T., CARNEY J., JARMAN J.D., HIGGINS B., MORRISON J.J. and LAFFEY J.G.: Effects and mechanismsof action of sildenafil citrate in human chorionic arteries. Reprod. Biol. Endocrinol., 7, 34, 2009.

8- LI L., XIE W., ZHENG X.L., YIN W.D. and TANG C.K.: A novel peptide adropin in cardiovascular diseases. Clin. Chim. Acta., 453: 107-13, 2016.

9- LOVREN F., PAN Y., QUAN A., SINGH K.K., SHUKLA P.C. and GUPTA M.: Adropin is a novel regulator of 
endothelial function. Circulation, 122 (11 Suppl.): S18592, 2010.

10- GOZAL D., KHEIRANDISH-GOZAL L. and BHATTACHARJEE R.: Circulating adropin concentrations in pediatric obstructive sleep apnea: Potential relevance to endothelial function. J. Pediatr., 163: 1122-6, 2013.

11-AYDIN S.: Three new players in energy regulation: Preptin, adropin and irisin, Peptides, 56: 94-110, 2014.

12- WANG H., GAO B., WU Z., WANG H. and DONG M.: Alteration of serum adropin level in preeclampsia. Pregnancy Hypertension: An International Journal of Women's Cardiovascular Health, 8 (2017): 6-8, 2017.

13- CAKMAK B.D., DUNDAR B., ACIKGOZ A.S., OZGEN G., CIFT T., AHMEDIAN R. and ALTEKIN Y.: The relationship between maternal and umbilical cord adropin levels with the presence and severity of preeclampsia. J. Perinat. Med., 45 (7): 879-85, 2017.

14-HUAI J., YANG Z., YI Y. and WANG G.: Different Effects of Pravastatin on Preeclampsia-like Symptoms in Different Mouse Models. Chinese., Medical Journal, February 20, Volume 131, Issue 4: 461-70, 2018.

15- MARCONDES F.K., BIANCHI F.J. and TANNO A.P.: Determination of the estrous cycle phases of rats: Some helpful considerations. Brazilian Journal of Biology, 62 (4): 609-14, 2002.

16- KLUKOVITS A., RÓBERT G., PÉTER S., GÁBOR J. and GEORGE F.: Functional and histochemical characterization of a uterine adrenergic denervation process in pregnant rats. Biology of Reproduction, 67: 1013-7, 2002.

17- NOVELLI E.L., DINIZ Y.S., GALHARDI C.M., EBAID G.M., RODRIGUES H.G., MANI F., FERNANDES A.A., CICOGNA A.C. and NOVELLIFILHO J.L.: Anthropometrical parameters and markers of obesity in rats., Lab. Anim., 41 (1): 111-9, 2007.

18- NISHI H. and ELIN R.: Three turbidimetric methods for determining total protein compared. Clin. Chem., 31: 1377-80, 1985.

19- ABUBAKAR M., UKWUANI A. and MANDE U.: Antihypertensive activity of Hibiscus Sabdariffa aqueous calyx extract in Albino rats. Sky Journal of Biochemistry Research, 4 (3): 16-20, 2015.

20- DAS B., SAHA-ROY S., GUPTA A D., LAHIRI T.K. and DAS H.N.: Assessment of Placental Oxidative Stress in Pre-Eclampsia Obstet. Gynaecol. India. Feb., 62 (1): 3942, 2012.

21- KAKKAR P., DAS B. and VISWANATHAN P.N.: A modified spectrophotometric assay of superoxide dismutase. Indian J. Biochem. Biophys., 21: 130-2.32, 1984.

22- REDDY K.P., SUBHANI S.M., KHAN P.A. and KUMAR K.B.: Effect of light and benzyl adenine on dark-treated growing rice leaves, II changes in peroxidase activity. Plant. Cell Physiol., 24: 987-94, 1995.

23- OHKAWA H., OHISHI N. and YAGI K.: Assay for lipid peroxides in animals and tissue by thiobarbituric acid reaction. Anal. Biochem., 95: 351-8, 1979.

24- BANCROFT J.D. and GAMBLE M.: Theory and Practice of Histological Techniques. ${ }^{6 \mathrm{t}}$ Edition, Churchill Livingstone, Elsevier, China, 2008.
25- TIETZ N.W.: Clinical guide to laboratory tests. Pbl. W.B. Saunders, Co., Philadelphia, pp. 509-12, 1995.

26- JAFFÉ M.: On the precipitate which produces picric acid in normal urine and on a new reaction of creatinine. $\mathrm{Z}$. Physiol. Chem., 10: 391-400, 1986.

27- TEMPLE R.C., CLARK P.M. and HALES C.N.: Measurement of insulin secretion in typ9e II diabetes: Problems and pitfalls. Diabetic Medicine, 9 (6): 503-12, 1992.

28- MATTHEWS D.R., HOSKER J.P., RUDENSKI A.S., NAYLOR B.A. and TURNER R.C.: Homeostasis model assessment: Insulin resistance and beta-cell function from fasting plasma glucose and insulin concentrations in man. Diabetologia, 28 (7): 412-9, 1985.

29- NAUK M., MARZ W. and JARAUSCH J.: Multicenter evaluation of homogenous assay for HDL-Cholesterol without sample pretreatment. Clin. Chem., 43 (9): 1622 9, 1997.

30- FRIEDWALD W.T., LEVY R.I. and FREDRICKSON D.S.: Estimation of the concentration of low-density lipoprotein cholesterol in plasma, without use of the preparative ultracentrifuge. Clin. Chem., 18: 499-502, 1972.

31- NAITO H.K.: Triglycerides in clinical chemistry: Theory, analysis and correlation. Pbl. Kaplan L.A. and Pesce A.J., U.S.A., pp. 997, 1989.

32- RIDKER P.M., RIFAI N., PFEFFER M.A., SACKS F.M., MOYE L.A., GOLDMAN S., FLAKER G.C. and BRAUNWALD E.: Inflammation, Pravastatin and the risk of coronary events after myocardial infarction in patients with average cholesterol levels. Circulation, 98 (9): 839-44, 1998.

33- ZHOU Q., SHEN J., ZHOU G., SHEN L. and ZHOU S.: Effects of magnesium sulfate on heart rate, blood pressure variability and baroreflex sensitivity in preeclamptic rats treated with L-NAME. Hypertension Pregnancy, 32: 42231, 2013.

34- AMARAL T.A.S., OGNIBENE D.T., CARVALHO L.C.R.M., ROCHA A.P.M., COSTA C.A., MOURA R.S and RESENDE A.C.: Differential responses of mesenteric arterial bed to vasoactive substances in L-NAME-induced preeclampsia: Role of oxidative stress and endothelial dysfunction. Clin. Exp. Hypertens., 40 (2): 126-35, 2018.

35- PAAUW N.D., TERSTAPPEN F., GANZEVOORT W., JOLES J.A., GREMMELS H. and LELY A.T.: Sildenafil during Pregnancy: A Preclinical Meta-Analysis on Fetal Growth and Maternal Blood Pressure. Hypertension, 70 (5): 998-1006, 2017.

36- WEI G., DAWSON V.L. and ZWEIER J.L.: Role of neuronal and endothelial nitric oxide synthase in nitric oxide generation in the brain following cerebral ischemia Biochimica et Biophysica Acta (BBA)-Molecular Basis of Disease, Volume 1455, Issue 1, Pages 23-34, 1999.

37- MATSUBARA K., MATSUBARA Y., HYODO S., KATAYAMA T. and ITO M.: Role of nitric oxide and reactive oxygen species in the pathogenesis of preeclampsia. J. Obstet. Gynaecol. Res., 36: 239-47, 2010.

38- CRAICI I.M., WAGNER S.J., BAILEY K.R., FITZGIBBON P.D., WOOD-WENTZ C.M., TURNER S.T., HAYMAN S.R, WHITE W.M., BROST B.C., ROSE C.H., GRANDE J.P. and GAROVIC V.D.: Podocyturia predates 
proteinuria and clinical features of preeclampsia: Longitudinal prospective study. Hypertension, 61: 1289-96, 2013.

39- MURPHY R., LAMARCA B., COCKRELL K. and GRANGER J.: Role of Endothelin in Mediating Soluble fms-Like Tyrosine Kinase 1-Induced Hypertension in Pregnant Rats. Hypertension, 55: 394-8, 2010.

40- SANDRIM V.C., PALEI A.C., METZGER I.F., GOMES V.A., CAVALLI R.C. and TANUSSANTOS J.E.: Nitric oxide formation is inversely related to serum levels of antiangiogenic factors soluble fms-like tyrosine kinase1 and soluble endoglin in preeclampsia. Hypertension, 52: 402-7, 2009.

41- MUTTER W.P. and KARUMANCHI S.A.: Molecular mechanisms of pre-eclampsia. Microvasc. Res., 75: 1-8, 2008.

42- HARIHARAN B.S., SHOEMAKER M.D. and WAGNER S.: Pathophysiology of Hypertension in Preeclampsia. Clin. Pract., 13 (2): 33-7, 2016.

43- GRANGER J.P., ALEXANDER B.T., LLINAS M.T., BENNETT W.A. and KHALIL R.A.: Pathophysiology of hypertension during preeclampsia linking placentalischemia with endothelial dysfunction. Hypertension, 38: 718-22, 2001.

44- MA R.Q., SUN M.N. and YANG Z.: Inhibition of nitric oxide synthase lowers fatty acid oxidation in preeclampsialike mice at early gestational stage. Chin. Med. J. (Engl)., 124 (19): 3141-7, 2011.

45- RAMESAR S.V., MACKRAJ I., GATHIRAM P. and MOODLEY J.: Sildenafil citrate improves fetal outcomes in pregnant, L-NAME treated, Sprague-Dawley rats. European Journal of Obstetrics, Gynecology, and Reproductive Biology, 149: 22-6, 2010.

46- SADLER C.J. and WILDING J.P.: Reduced ventromedial hypothalamic neuronal nitric oxide synthase and increased sensitivity to NOS inhibition in dietary obese rats: Further evidence of a role for nitric oxide in the regulation of energy balance. Brain Res., 1016, pp. 222-8, 2004.

47- IURAS A., TELLES M.M., BERTONCINI C.R., De ANDRADE, SILVEIRA V.L. and RIBEIRO E.B.: Central administration of a nitric oxide precursor abolishes both the hypothalamic serotonin release and the hypophagia induced by interleukin-1beta in obese Zucker rats Regul. Pept., 124 pp. 145-50, 2005.

48- De MOURA R.S., RESENDE A.C., MOURA A.S. and MARADEI M.F.: Protective action of a hydroalcoholic extract of a vinifera grape skin on experimental preeclampsia in rats. Hypertens Pregnancy, 26 (1): 89-1006 (3): 172-80, 2010, 2007.

49- ELSAMANOUDY A.Z. and ABBAS A.M.: Endothelial Dysfunction and Insulin Resistance as Pathophysiologic mechanisms in a Rat Model of preeclampsia. American Journal of Biochemistry and Biotechnology, 6 (3): 172$80,2010$.

50- ANIM-NYAME N., GAMBLE J., SOORANNA S.R., JOHNSON M.R. and STEER P.J.: Relationship between insulin resistance and tissue blood flow in preeclampsia, J. Hypertens, 5 (33): 1063-1057, 2015.

51- GHOSH A., FREESTONE N., ANIM-NYAME N. and ARRIGONI F.: Microvascular function in pre-eclampsia is influenced by insulin resistance and an imbalance of angiogenic mediators. Physiological Reports, Volume 5, Issue 8, e13185, 2017.

52- SADRI P. and LAUTT W.W.: Blockade of hepatic nitric oxide synthase causes insulin resistance. Am. J. Physiol., 277 (1 Pt 1): G101-8, 1999.

53- GOPAUL N.K., MANRAJ M.D., HEBE A., LEE KWAI Y.S., JOHNSTON A., CARRIER M.J. and ANGGARD E.E.: Oxidative stress could precede endothelial dysfuncti on and insulin resistance in Indian Mauritians with impaired glucose metabolism. Diabetologia, 44: 706-12, 2001.

54- DING X., YANG Z., HAN Y. and YU H.: Fatty acid oxidation changes and the correlation with oxidative stress in different preeclampsia-like mouse models. PLoS One; 9: e109554, 2014.

55- PIMENTEL A.M., PEREIRA N.R., COSTA C.A., MANN G.E., CORDEIRO V.S., et al.: L-arginine-nitric oxide pathway and oxidative stress in plasma and platelets of patients with pre-eclampsia. Hypertens Res., 36: 783-8, 2013.

56- LI F., YANG Z., ZHANG A., SUN X., WANG J. and MENG R.: The changes of LCHAD in preeclampsia with different clinical features and the correlation with NADPH P47-phox, p38MAPK- $\alpha$, COX-2 and serum FFA and TG. [Article in Chinese]. Zhonghua Fu Chan Ke Za Zhi, 50 (2): 92-100, 2015.

57- SUN M.N., YANG Z. and MA R.Q.: Interaction of fatty acid oxidation with oxidative stress in preeclampsia-like mouse model at multiple stages of gestation. Zhonghua Yi Xue Za Zhi, 91 (33): 2343-7, 2011.

58- YANG X., GUO L., SUN X., CHEN X. and TONG X.: Protective effects of hydrogen-rich saline in preeclampsia rat model. Placenta, 32: 681-6, 2011.

59- SASSER J.M. and BAYLIS C.: Effects of sildenafil on maternal hemodynamics and fetal growth in normal rat pregnancy. Am. J. Physiol. Regul. Integr. Comp. Physiol., 298: 433-8, 2010.

60- VON DADELSZEN P., DWINNELL S., MAGEE L.A., CARLETON B.C., GRUSLIN A., LEE B., LIM K.I., LISTON R.M., MILLER S.P., RURAK D., SHERLOCK R.L., SKOLL M.A., WAREING M.M. and BAKER P.N.: Sildenafil citrate therapy for severe early-onset intrauterine growth restriction. B.J.O.G., 118: 624-8, 2011.

61- ZOMA W.D., BAKER R.S. and CLARK K.E.: Effects of combined use of sildenafil citrate (Viagra) and $17 \mathrm{~b}$ estradiol on ovine coronary and uterine hemodynamics. Am. J. Obstet. Gynecol., 190: 1291-7, 2004.

62- DASTJERDI M.V., HOSSEINI S. and BAYANI L.: Sildenafil citrate and uteroplacental perfusion in fetal growth restriction. J. Res. Med. Sci., 17: 632-6, 2012.

63- RAMESAR S.V., GATHLRAM P., MOODLEY J. and MACKRAJ I.: Treatment of pre-eclampsia: Implementing research findings. Gynecol. Obstetric., 2, 117, 2012.

64- GILLIS E.E., MOONEY J.N., GARRETT M.R., GRANGER J.P. and SASSER J.M.: Sildenafil treatment ameliorates the maternal syndrome of preeclampsia and rescues fetal growth in the Dahl Salt Sensitive rat. Hypertension, 67 (3): 647-53, 2016. 
65- HERRAIZ S., PELLICER B., SERRA V., CAULI O., CORTIJO J., FELIPO V. and PELLICER A.: Sildenafil citrate improves perinatal outcome in fetuses from preeclamptic rats. British Journal of Obstetrics and Gynecology, 119: 1394-402, 2012.

66- AYALA J.E., BRACY D.P., JULIEN B.M., ROTTMAN J.N., FUEGER P.T. and WASSERMAN D.H.: Chronic treatment with sildenafil improves energy balance and insulin action in high fat-fed conscious mice. Diabetes, 56, pp. 1025-33, 2007.

67- TOPUZ M., CELIK A. and ASLANTA S T.: Plasma adropin levels predict endothelial dysfunction like flowmediated dilatation in patients with type 2 diabetes mellitus. J. Investig. Med., 61: 1161-4, 2013.

68- CHEN M., OUYANG F. and ZHOU S.: Adropin as a novel energy factor likely has the ability to regulate blood pressure, Med. Hypotheses, 85 (2): 234, 2015.

69- GU X., LI H., ZHU X., GU H., CHEN J., WANG L., HARDING P. and XU W.: Inverse correlation between plasma adropin and ET-1 levels in essential hypertension: A cross-sectional study, Medicine (Baltimore), 94 (40): e1712, 2015.

70- GULEN B., EKEN C., KUCUKDAGLI O.T., SERINKEN M., KOCYIGIT A., KILIC E. and UYAREL H.: Adropin levels and target organ damage secondary to high blood pressure in the ED. Am. J. Emerg. Med. Nov., 34 (11): 2061-4, 2016.

71- BOLAYIR H.A., KIVRAK T., GUNES H., BOLAYIR A. and KARACA I.: Adropin and circadian variation of blood pressure Kardiol Pol.,76 (4): 776-82, 2018.

72- CELIK E., YILMAZ E., CELIK O., ULAS M., TURKCUOGLU I. and KARAER A.: Maternal and fetal adropin levels in gestational diabetes mellitus. J. Perinat. Med., 41: 375-80, 2013.

73- BAKA S., MALAMITSI-PUCHNER A., BRIANA D.D., BOUTSIKOU M., MARMARINOS A. and GOURGIOTIS D.: Adropin concentrations in termpregnancies with normal, restricted and increased fetal growth. J. Matern. Fetal. Neonatal. Med., 29: 2403-7, 2016.

74- QIU X., HE J.R., ZHAO M.G., KUANG Y.S., XU S.Q. and ZHANG H.Z.: Relationship between human cord blood adropin levels and fetalgrowth. Peptides, 52: 1922, 2014.

75- AYDIN H.I., ESER A., KAYGUSUZ I., YILDIRIM S., CELIK T. and GUNDUZ S.A.: Adipokine, adropin and endothelin-1 levels in intrauterine growth restricted neonates and their mothers. J. Perinat. Med., 76-44: 669, 2016.

76- DABROWSKI F.A., JARMUŻEK P., GONDEK A.1., CỦDNOCH-JEDDRZEJEWSKA A., BOMBA-OPOЙ D. and WIELGOS M.: First and third trimester serum concentrations of adropin and copeptin in gestational diabetes mellitus and normal pregnancy Ginekol. Pol., 87 (9): 62934, 2016.
77- HOSSEINI A., SHANAKI M., EMAMGHOLIPOUR, NAKHJAVANI M., RAZI F. and GOLMOHAMMADI T.: Elevated Serum Levels of Adropin in Patients with Type 2 Diabetes Mellitus and its Association with Insulin Resistance J. Biol. Today's World, 5 (3): 44-9, 2016.

78- YILDIRIM B., CELIK O. and AYDIN S.: Adropin: A key component and potential gate keeper of metabolic disturbances in polycystic ovarian syndrome. Clin. Exp. Obstet. Gynecol., 41: 310-2, 2014.

79- KUMAR K.G., TREVASKIS J.L., LAM D.D., SUTTON G.M., KOZA R.A., CHOULJENKO V.N., KOUSOULAS K.G., ROGERS P.M. and BUTLER A.A.: Identification of adropin as a secreted factor linking dietary macronutrient intake with energy homeostasis and lipid metabolism, Cell. Metab., 8 (6): 468-81, 2008.

80- GAO S., McMILLAN R.P., ZHU Q., LOPASCHUK G.D., HULVER M.W. and BUTLER A.A.: Therapeutic effects of adropin on glucose tolerance and substrate utilization in diet-induced obese mice with insulin resistance. Mol. Metab., 4 (4): 310-24, 2015.

81- AKCILAR R., KOCAK F.E., SIMSEK H., AKCILAR A., BAYAT Z. and ECE E.: The effect of adropin on lipid and glucose metabolism in rats with hyperlipidemia. Iran J. Basic Med. Sci., 19: 245-51, 2016.

82- KALU ŻNA M., HOPPE K., SCHWERMER K., IBRAHIM A., PAWLACZYK K. and ZIEMNICKA K.: Adropin and irisin levels in relation to nutrition, body composition, and insulin resistance in patients with end-stage renal disease on chronic hemodialysis and peritoneal dialysis, Polskie Archiwum Medycyny Wewn etrznej, 126 (7-8), 2016.

83- BUTLER A.A., TAM C.S. and STANHOPE K.L.: Low circulating adropin concentrations with obesity and aging correlate with risk factors for metabolic disease and increase after gastric bypass surgery in humans. J. Clin. Endocrinol. Metab., 97: 3783-91, 2012.

84- YU H.Y., ZHAO P. and WU M.C.: Serum adropin levels are decreased in patients with acute myocardial infarction. Regul. Pept., 190-91: 46-9, 2014.

85- CHANG J., CHU N., LIN F., HSU J. and CHEN P.: Relationship between plasma adropin levels and body composition and lipid characteristics amongst young adolescents in Taiwan. Obesity Research \& Clinical Practice, Volume 12, Issue 1, Supplement 1, Pages 1017, 2018.

86- NOWAK J., KULIK-KUPKA K., ZIELEN-ZYNEK I., KOWALSKA J., HUDZIK B., BEDKOWSKASZCZEPANSKA A., ZYLA A. and ZUBBLEWICZ SZKODZINSK B.: Adropin concentration correlates with selected anthropometric and biochemical parameterspreliminary report. Endocrine Abstracts, 56: P297, 2018.

87- YANG C., DEMARS K.M. and CANDELARIO-JALIL E.: Age-Dependent Decrease in Adropin is Associated with Reduced Levels of Endothelial Nitric Oxide Synthase and Increased Oxidative Stress in the Rat Brain. Aging Dis., 9 (2): 322-30, 2018. 


\section{مستويات هرمون الآدروبين فى مصل نموذج الجرذان المصابة بتسميم الحمل



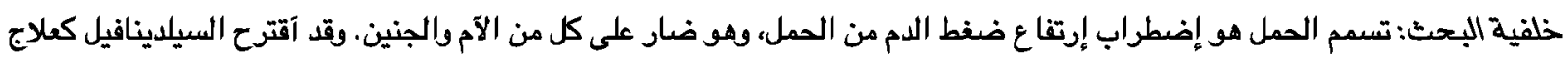

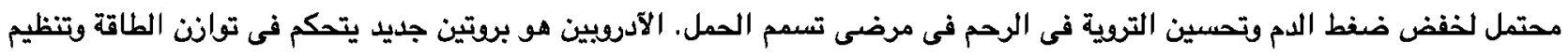

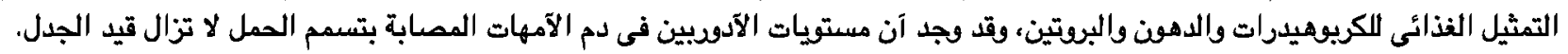

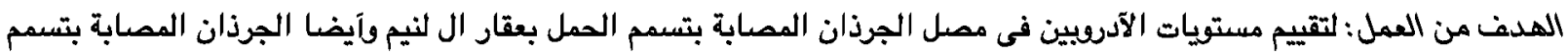
الحمل والمعالجة بعقار السلدنافيل سيترات وللتحقق من إرتباطها بيعض الهئ المعلمات الآيضية ودلائل الإلتهابات والآكسدة.

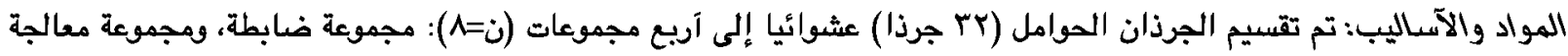



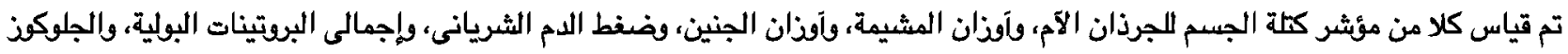

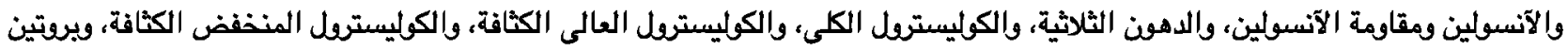

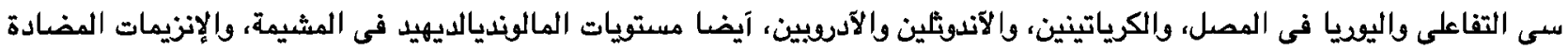







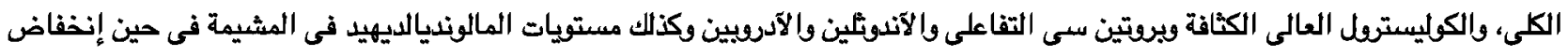

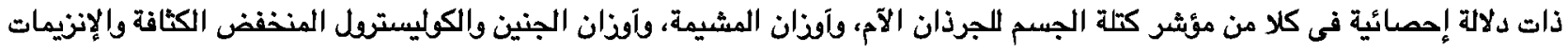





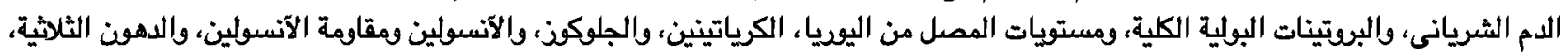

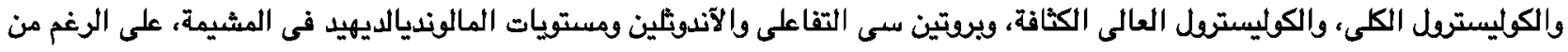



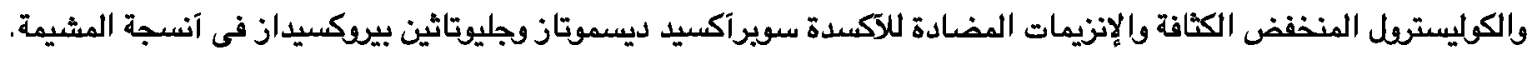

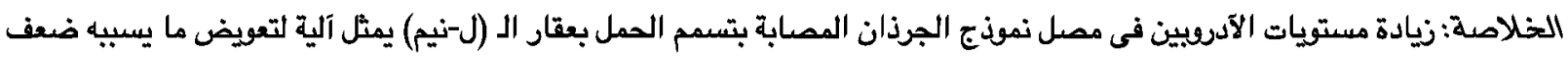

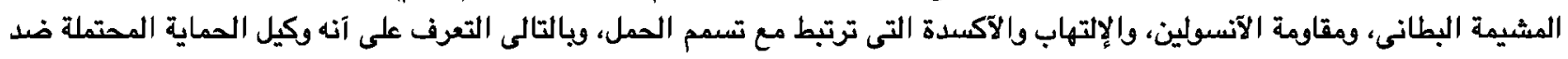

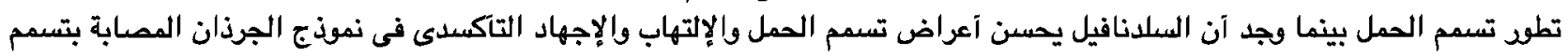

